\title{
Pemodelan Arsitektur Data pada Perguruan Tinggi (Studi Kasus : UMMagelang)
}

\author{
Mukhtar Hanafia ${ }^{\mathrm{a}}$ Ardhin Primadewi ${ }^{\mathrm{b}}$, Sunarnic \\ ${ }^{a}$ Fakultas Teknik, Universitas Muhammadiyah Magelang, hanafi@ummgl.ac.id \\ ${ }^{\mathrm{b}}$ Fakultas Teknik, Universitas Muhammadiyah Magelang, ardhin@ummgl.ac.id \\ ${ }^{c}$ Fakultas Teknik, Universitas Muhammadiyah Magelang, sunarni@ummgl.ac.id
}

\begin{abstract}
Public services becomes main issue in the provision of public services, especially at higher education as one of the public sector in the field of education. It needs innovation directly in developing service system, especially on employee of higher education with good governance principle. The development depends on "Pusat Data dan Sistem Informasi UMMagelang". However, the control and development control of the system is autonomously assigned to each department in the institution. So the system is not developed based on the business function that is executed or the required data entity, but limited to the spontaneity of short-term needs. It needs an in-depth relationship analysis between the development of information systems with business functions running as well as data entity required. This research is using Zachman Framework which has advantages in the depth of analysis in the data architecture as modelling method. The research relates 3 variables such as business functions, data entities and applications that facilitate the identification of positions that need to be addressed immediately.
\end{abstract}

Keywords: data architecture, data modelling, zachman framework, higher education

\begin{abstract}
Abstrak
Pelay anan publik menjadi isu utama dalam penyediaan layanan publik khususnya pada perguruan tinggi sebagai salah satu sektor publik pada bidang pendidikan. Perlu inovasi secara terarah dalam mengembangkan sistem pelay anan khususnya pada civitas akademika dengan prinsip good governance. Pengembangan ini sangat tergantung pada Pusat Data dan Sistem Informasi UMMagelang. Namun demikian. kendali dan kontrol pengembangan sistem diserahkan secara otonomi pada masing-masing biro tataran institusi. Sehingga sistem yang dikembangkan bukan berdasarkan pada fungsi bisnis yang dijalankan ataupun entitas data y ang diperlukan, namun sebatas spontanitas kebutuhan jangka pendek. Perlu adany a analisa y ang mendalam terkait relasi antara pengembangan sistem informasi dengan fungsi bisnis y ang berjalan serta entitas data y ang dibutuhkan. Pemodelan y ang digunakan pada penelitian ini menggunakan Zachman Framework y ang memiliki kelebihan dalam kedalaman analisa pada arsitektur data. Penelitian ini dengan merelasikan 3 variabel yaitu fungsi bisnis, entitas data dan aplikasi yang memudahkan identifikasi posisi-posisi mana y ang perlu segera dibenahi.
\end{abstract}

Kata kunci: arsitektur data, pemodelan data, zachman framework, perguruan tinggi

(C) 2018 Jurnal RESTI

\section{Pendahuluan}

Isu pelayanan publik saat ini merupakan isu penting dalam penyediaan layanan publik di Indonesia Sedangkan pelayanan merupakan proses pemenuhan kebutuhan pengguna sistem oleh penyedia sistem [1]. TIK sebagai bagian dari e-business dalam manajemen Pelayanan tidak hanya dibutuhkan pada organisasi perguruan tinggi menjadi tolak ukur perkembangan bisnis, tetapi juga berkembang lebih luas pada seluruh business intelligence pada setiap perguruan tinggi [5]. tatanan organisasi baik pemerintah ataupun Perguruan tinggi sebagai salah satu sektor publik pada pendidikan[2]. Proses pelayanan saat ini sangat bidang pendidikan juga mengedepankan pelayanan bergantung dengan teknologi informasi dan komunikasi terutama kepada civitas akademika yang menjadi tulang [3] yang selanjutnya disebut TIK. TIK dalampandangan punggung keberhasilan manajemen perguruan tinggi. sempit terkait hardware, software, database, networks, Perlu inovasi secara terarah dalam mengembangkan

Diterima Redaksi : 15-03-2018 $\mid$ Selesai Revisi : 05-04-2018 | Diterbitkan Online : 16-04-2018 
pelayanan civitas akademika yang sesuai dengan prinsip dan potensi pasar pada setiap elemen manajemen good governance sehingga memiliki akuntabilitas serta perguruan tinggi [6]. Kemudian dilanjutkan pada tahun transparansi data [2]. Perlu adanya kemudahan secara 2009 menggunakan framework COBIT [4] dan teknologi yang mendukung seluruh kegiatan civitas dilanjutkan tahun 2011 menggunakan metodologi IT akademik perguruan tinggi [6] berupa implementasi Balance Scorecard [8] dalam mengevaluasi penerapan business intelligence pada perguruan tinggi yang TIK pada perguruan tinggi. Pada tahun 2014, penelitian terintegrasi dengan data pada seluruh unit pada dilanjutkan dengan perancangan infrastrukture-business perguruan tinggi secara real-time [7].

Pengembangan pelayanan pada civitas akademika pada UMMagelang sangat tergantung pada Pusat Data dan Sistem Informasi UMMagelang (yang selanjutnya disebut PDSI) sebagai Biro pengembang sistem tataran institusi. Namun demikian, kendali dan kontrol pengembangan sistem diserahkan secara otonomi pada masing-masing biro tataran institusi. Sehingga sistem yang dikembangkan bukan berdasarkan pada fungsi bisnis yang dijalankan ataupun entitas data yang diperlukan, namun sebatas apa yang secara kasat mata dibutuhkan biro-biro terkait. Hal ini menunjukkan bahwa pengembangan business intelligence di lingkungan UMMagelang bersifat sporadis [5] atau spontanitas [7]. Hal tersebut diatas menunjukkan bahwa 2.3 Enterprise Architecture Planning belum adanya analisa yang mendalam terkait hubungan antara pengembangan sistem informasi dengan fungsi bisnis yang berjalan serta entitas data yang dibutuhkan. Rumusan masalah dalam penelitian ini bagaimana memodelkan arsitektur data yang dapat mendukung pengembangan business intelligence pada perguruan tinggi?

Tujuan penelitian ini adalah menemukan kebutuhan data yang terlupakan pada rangkaian proses bisnis pada sebuah perguruan tinggi. Penemuan entitas data ini sebagai pondasi dalam pembenahan rencana pengembangan sistem informasi dan teknologi informasi institusi perguruan tinggi. Tentunya pembenahan ini tidak luput dari keselarasan visi misi institusi perguruan tinggi. Pemodelan yang digunakan pada penelitian ini menggunakan Zachman Framework yang memiliki kelebihan dalam kedalaman analisa khususnya pada arsitektur data.

\section{Tinjauan Pustaka}

Pada era globalisasi, peranan TIK sangat vital dalam perbaikan manajemen perguruan tinggi. Perguruan tinggi sebagai bagian dari dunia pendidikan yang mengutamakan pelayanan kepada stakeholder-nya, menjadikan TIK sebagai salah satu faktor utama dalam memunculkan daya saing [7]. Daya Saing perguruan tinggi adalah kriteria yang digunakan untuk mengukur sejauh mana dukungan sistem pada perguruan tinggi akan dikembangkan sehingga dapat bertahan pada era globalisasi [6]. Berikut ini merupakan tinjauan pustaka yang mendukung penelitian ini

\subsection{Rekam Jejak Penelitian} pada perguruan tinggi baik arsitektur logis maupun fisik [9] dan dilanjutkan tahun 2017 terkait perencanaan strategis TIK dengan menyelaraskan visi misi organisasi dan perencanaan TIK sebagai pendukung utama [7].

\subsection{Business Intelligence}

Business intelligence merupakan suatu sistem yang memudahkan dalam mengumpulkan, menganalisa, menyimpan, serta menyediakan data - data yang dibutuhkan civitas akademika institusi perguruan tinggi [10]. Business intelligence mampu menjawab kebutuhan manajemen eksekutif perguruan tinggi untuk menganalisa masalah-masalah dan dalam pengambilan keputusan [7].

Enterprise Architecture (EA) merupakan suatu proses bagaimana sebuah organisasi memulai dan menghasilkan tatanan yang baik tentang implementasi teknologi informasi dan proses bisnis dalam organisasi [11], [12]. Pada penelitian ini framework yang digunakan adalah Enterprise Architecture Planning.

Enterprise Architecture Planning (yang selanjutnya disebut EAP) merupakan suatu pendekatan yang dibuat oleh Steven H. Spewak untuk membangun arsitektur enterprise berdas arkan kebutuhan data dan proses bisnis yang berjalan. EAP terdiri dari arsitektur data, arsitektur aplikasi dan arsitektur teknologi. Arsitektur disini sebagaimana layaknya cetak biru sebagai panduan untuk pengembangan informational dashboard secara keseluruhan pada perguruan tinggi [13]. Pada Gambar 1 ditunjukkan lapisan pada EAP yang mana pemodelan arsitektur data dapat dilihat pada lapis an ke-3.

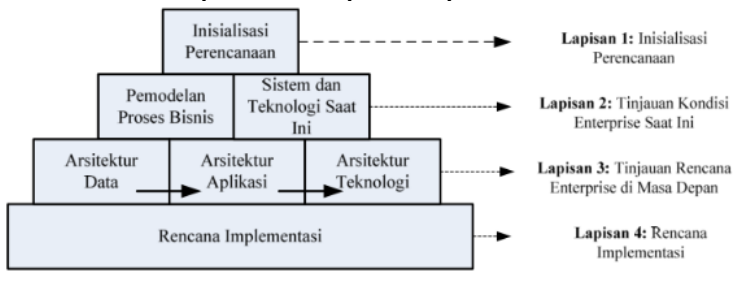

Gambar 1.Komponen dan Lapisan Enterprise Architecture Planning [3]

\subsection{Zachman Framework}

Pendefinisian arsitektur data pada EAP masih tergolong umum. Untuk lebih mendalami proses analisa, pendekatan pemodelan arsitektur data menggunakan zachman framework. Zachman framework merupakan salah satu kerangka kerja yang digunakan untuk mengembangkan arsitektur enterprise yang diperkenalkan oleh John Zachman sejak tahun 1987. 
Zachman framework merupakan suatu alat bantu yang

dikembangkan untuk memotret arsitektur organisasi dari a. Dokumentasi visi dan misi institusi

berbagai sudut pandang dan aspek, sehingga didapatkan b. Identifikasi dan definisi fungsi bisnis.

Gambaran organisasi secara utuh. Beberapa keunggulan c. Dokumentasi model bisnis utama, distribusi, dan dari zachman framework antara lain sangat mudah dipahami, karena mengacu kepada organisasi secara umum dan mengGambarkan tools dan metodologi presentasi kepada semua stakeholder institusi.

secara independen, komponen- komponen dapat Pada tahap ini merupakan lanjutan setelah proses bisnis dipetakan untuk menemukan kondisi yang paling cocok didefinisikan. Menganalisis data dan informasi yang ada dengan pemodelan arsitektur data pada seluruh bagian- dipilah berdasarkan fungsi bisnisnya. Pada tahap ini bagian berbeda dari infrastruktur TI melalui perspektif diperoleh matriks fungsibisnis dan entitas data yang ada yang berbeda [14].

\subsection{Value chain analysis}

Value chain analysis dibuat untuk mengidentifikasi dan mendefinisikan area bisnis dengan mengklasifikasikan area ke dalam bisnis utama (primary activities) dan Tahap akhir adalah mendefinisikan data utama bisnis pendukung (support activities) pada enterprise. yang dibutuhkan untuk mendukung aktifitas bisnis. Mengacu pada dokumen organisasi yang menyebutkan Arsitektur data terdiri dari entitas data yang memiliki tugas dan fungsi setiap unit kerja berdasarkan atribut dan relasi terhadap data yang lain. Pedoman pengamatan yang dilakukan terhadap proses kerja yang dalam mendefinisikan arsitektur data yaitu:

terjadi di masing-masing unit kerja [7].

\section{Metodologi Penelitian}

Penelitian yang dilakukan selama enam bulan ini memiliki tahapan yang ditunjukkan pada Gambar 2 dan dijelaskan pada sub bab berikutnya. dan yang belum ada. Termasuk memetakan data dan fungsi bisnis yang dibutuhkan untuk jangka panjang pada lingkup institusi.

\subsection{Data Architecture}

a. Daftarkan calon entitas data dengan meninjau model bisnis dan deskripsi sistem dan teknologi yang dipakai.

b. Tetapkan entitas yang akan dipakai.

c. Definisikan setiap entitas tersebut dan mendokumentasikannya

d. Hubungkan entitas data dengan fungsi bisnis detil.

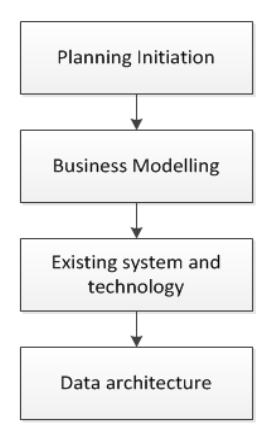

Gambar 2.Alur proses penelitian

\subsection{Planning Initiation}

Tahapan awal yang harus dilakukan adalah melakukan inisiasi perencanaan, dengan harapan proses pemodelan arsitektur dapat terarah dengan baik. Tahapan ini sebagai landasan berfikir tahap berikutnya. Pada tahap inilah ruang lingkup dan perencanaan kegiatan didefinisikan, menentukan metodologi yang akan digunakan, sumber daya yang terlibat dan menetapkan perangkat (tools) yang akan digunakan.

\subsection{Business Modelling}

Tahap berikutnya adalah pemodelan bisnis untuk menyediakan dasar pengetahuan yang lengkap dan menyeluruh yang dapat digunakan untuk mendefinisikan arsitektur dan rencana implementasinya. Ada 3 tahapan untuk memodelkan bisnis, yaitu sebagai berikut :

\section{Hasil dan Pembahasan}

Pada Pada setiap alur proses penelitian terdapat hasil dan pembahasan yang dijabarkan lebih detil pada masingmasing sub bab.

\subsection{Planning Initiation}

Pada tahap pertama, ruang lingkup pembahasan dibatasi pada fungsi bisnis yang telah diimplementasikan pada institusi (terutama pada sisi teknologi informasi) dan terbatas pada fungsi bisnis yang dapat meningkatkan pelayanan pada seluruh civitas akademik serta fungsi bisnis yang mendukung pada keterbutuhan data pada Akreditasi Institusi Perguruan Tinggi (AIPT). Metodologi yang digunakan adalah zachman framework dikarenakan rinci dalam pemodelan arsitektur data. Data yang dipetakan secara 3 dimensi $(x, y, z)$ ini dipecah menjadi bagian-bagian yang mudah untuk diGambarkan yaitu $(x, y),(x, z)$, dan $(y, z)$. Hasil dari pemetaan ini nantinya disebut sebagai matriks relasi.

\subsection{Business Modelling}

Tahap berikutnya adalah pemodelan bisnis yang diawali dengan dimulai dengan proses pengumpulan data primer dan sekunder dilanjutkan dengan pendefinisian sasaran dan kebijakan organisasi perguruan tinggi sebagai acuan. Proses ini diawali dengan mengumpulkan dokumen visi dam misi perguruan tinggi, dokumen Rencana Strategis Perguruan Tinggi serta Rencana Kerja pengembangan sistem pada PDSI UMMagelang 
serta mengidentifikasi proses bisnis dan fungsi bisnis yang berjalan di UMMagelang. Dari dokumen dan data primer yang didapatkan dapat dipetakan menggunakan Porter five forces competitive seperti pada Gambar 3. Pada Gambar 3 dapat diketahui bahwa stakeholder institusi terbagi menjadi 5 aspek yaitu competitor, new entrant, supplier, customer dan substitute. New entrant, competitor dan substitute menjadi ancaman bagi institusi jika tidak menaikkan daya saing kompetitif. Sedangkan supplier dan customer menjadi kesempatan dalam menaikkan daya saing kompetitif tersebut.

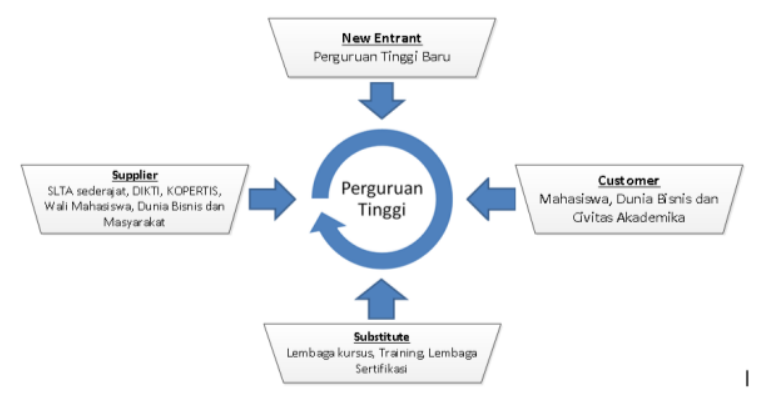

Gambar 3.Stakeholder Institusi

Menindaklanjuti stakeholder yang dapat menaikkan daya saing kompetitif institusi, kemudian informasi proses bisnis dan fungsibisnis yang sudah berjalan pada UMMagelang dapat didefinisikan yaitu : proses Penerimaan Mahasiswa Baru (PMB), proses akademik, perpustakaan, pengembangan Soft Skill, profil lulusan serta Penelitian dan Pengabdian Masyarakat.

\subsection{Existing System and Technology}

Hasil data yang dikolektif dari dokumen, hasil observasi dan wawancara kemudian diolah menggunakan value chain analysis yang dapat membagi aktivitas utama dan aktivitas pendukung pada proses bisnis dan fungsibisnis UMMagelang.

Kumpulan aktivitas yang dilakukan di UMMagelang yang saling berhubungan dalam menciptakan nilaiuntuk mencapai visi, misi, dan tujuan institusi agar dapat mendukung proses Akreditasi Institusi Perguruan Tinggi (AIPT) diGambarkan berdasarkan value chain analysis Michael E. Porter seperti yang ditunjukkan pada Gambar 4.

Dapat dilihat pada Gambar 4 bahwa value chain analysis UMMagelang terdiri atas aktivitas utama dan aktivitas pendukung yang saling berhubungan dalam proses penciptaan nilai. Aktivitas utama (primary activities) terdiri dari proses Penerimaan Mahasiswa Baru (PMB), proses akademik, perpustakaan serta Penelitian dan Pengabdian Masyarakat. Sedangkan aktivitas pendukung (secondary activities) meliputi profil lulusan dan pengembangan Soft Skill.

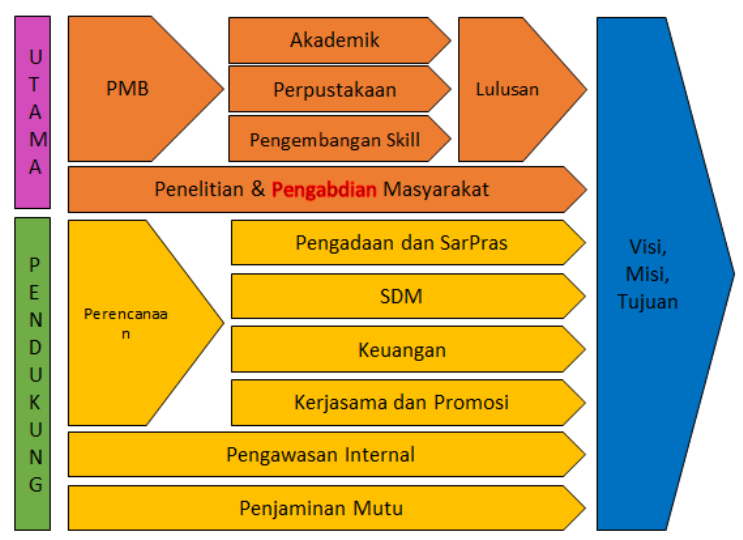

Gambar 4.Value chain analysis fungsi bisnis UMMagelang

Penjabaran dari aktivitas utama dan pendukung, dapat diidentifikasi entitas data dari fungsi bisnis yang sudah dipetakan, yaitu : panitia, calon MABA, ujian seleksi, hasil ujian, registrasi, mahasiswa, program studi, kurikulum, dosen, mata kuliah, jadwal kuliah, ruang, rencana studi, ujian, nilai, cuti, TA/skripsi, laporan, yudisium, wisuda, presensi, berita acara dan RPS mata kuliah.

\subsection{Data Architecture}

Setelah fungsi bisnis dan entitas data diidentifikasi pada sub bab sebelumnya, dilanjutkan dengan pemetaan untuk mencari hubungan (relasi). Hubungan ini didefinisikan melalui sebuah matriks hubungan antara entitas data dengan fungsi bisnis. Masing-masing sel dalam matriks untuk menentukan data entitas yang di create (C) yaitu fungsi untuk membuat data, read/reference $(\mathrm{R})$ yaitu fungsi yang menggunakan data dan update $(\mathrm{U})$ yaitu fungsi yang mengubah atau mengupdate data. Terdapat 3 pemetaan yang merupakan turunan darihubungan 3 dimensi pada fungsibisnis yang berjalan, yaitu :

a) Pemetaan fungsi bisnis ke entitas data $(\mathrm{x}, \mathrm{z})$ Setiap entitas data yang telah didefinisikan dihubungkan dengan area fungsi bisnis. Hubungan antara entitas data dengan area fungsi bisnis adalah dalam hal pengolahan dan penggunaan data untuk keperluan pemenuhan tujuan fungsi bisnis. Lebih jelasnya dapat dilihat pada tabel 1 .

Pada tabel 1 baris yang berwarna kuning merupakan representasi klasifikasi pada fungsi bisnis. Dari fungsi bisnis yang ada maka akan dipetakan pada entitas data yang dibutuhkan. Warna hijau pada entitas data merupakan entitas data yang belum terealisasi saat ini pada sistem di PDSI UMMagelang. Sedangkan warna hijau yang tersebar baik pada angka 1, 2 ataupun 3 menunjukkan bahwa data ini belum teraplikasikan pada sistem di PDSI UMMagelang. 
Mukhtar Hanafi, Ardhin Primadewi, Sunarni

Jurnal RESTI (Rekayasa Sistem dan Teknologi Informasi) Vol . 2 No. 1 (2018) 337 - 344

Tabel 1 Aliran Data Matriks Relasi Entitas Data terhadap Fungsi Bisnis

\begin{tabular}{|c|c|c|c|c|c|c|c|c|c|c|c|c|c|c|c|c|c|c|c|c|c|c|c|c|c|}
\hline & Entitas Data & & 定 & $\frac{v}{d}$ & & 氧 & & & & & 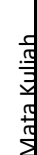 & 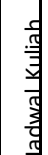 & & 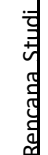 & & 整 & & & & & & $\begin{array}{l}\frac{\pi}{\pi} \\
\frac{0}{0} \\
\frac{\pi}{\pi} \\
\frac{\pi}{2} \\
0\end{array}$ & $\begin{array}{l}\frac{\pi}{3} \\
\frac{\pi}{\pi} \\
\frac{\pi}{\pi} \\
\sum \\
w \\
\frac{n}{\sigma}\end{array}$ & 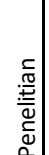 & 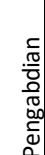 \\
\hline \multirow{9}{*}{$\sum_{a}^{\infty}$} & Perencanaan kegiatan PMB & & & & & & & & & & & & & & & & & & & & & & & & \\
\hline & $\begin{array}{l}\text { Penetapan Standarisasi dan } \\
\text { Kapasitas Mhs }\end{array}$ & 1 & & 1 & 1 & 1 & & 1 & & & & & & & & & & & & & & & & & \\
\hline & Pembuatan Jadwal PMB & 1 & & 1 & & 1 & & & & & & 1 & & & & & & & & & & & & & \\
\hline & Proses PMB & & & & & & & & & & & & & & & & & & & & & & & & \\
\hline & Penyusunan Materi Ujian PMB & 1 & & 3 & & & & & & & & & & & & & & & & & & & & & \\
\hline & $\begin{array}{l}\text { Penerimaan pendaftaran calom } \\
\text { MABA }\end{array}$ & 1 & 3 & & & & & & & & & & & & & & & & & & & & & & \\
\hline & Pelaksanaan Ujian Seleksi Masuk & & 1 & 2 & & & & & & & & & 1 & & & & & & & & & & & & \\
\hline & $\begin{array}{l}\text { Pemeriksaan Hasil UjianSeleksi } \\
\text { Masuk }\end{array}$ & 1 & 1 & 1 & 3 & & & & & & & & & & & & & & & & & & & & \\
\hline & Penetapan Kelulusan Calon MABA & 1 & 2 & 1 & 2 & 3 & 3 & 1 & & & & & & & & & & & & & & & & & \\
\hline \multirow{19}{*}{ 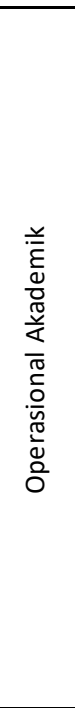 } & $\begin{array}{l}\text { Perencanaan Operasional } \\
\text { Akademik }\end{array}$ & & & & & & & & & & & & & & & & & & & & & & & & \\
\hline & Penetapan Kurikulum & & & & & & & 1 & 3 & & 3 & & & & & & & & & & & & 3 & & \\
\hline & Penetapan Kalender Akademik & & & 1 & & 1 & & 1 & & & & 1 & & & & & & & & & & & & & \\
\hline & Penetapan Dosen & & & & & & 1 & & & 2 & 1 & 1 & & & & & & & & & & & & & \\
\hline & Penawaran Mata Kuliah & & & & & & & 1 & 1 & & 3 & & & & & & & & & & & & 1 & & \\
\hline & Penyusunan Jadwal Kuliah & & & & & & & 1 & 1 & 1 & 1 & 3 & 1 & & & & & & & & & & & & \\
\hline & Penetapan Ruang Kuliah & & & & & & 1 & 1 & & & & 1 & 3 & & & & & & & & & & & & \\
\hline & Kebijakan Akademik & & & & & & & & & & & & & & & & & & & & & & & & \\
\hline & Registrasi Mahasiswa Lama & & & & & 3 & 2 & 1 & & & & & & 3 & & & & & & & . & & & & \\
\hline & Bimbingan Akademik & & & & & & 1 & 1 & & 1 & 2 & & & 2 & & 1 & & & & & & & & & \\
\hline & Pemrosesan Rencana Studi & & & & & 2 & 1 & 1 & 1 & 1 & 2 & 1 & & 3 & & 1 & & & & 1 & & & & & \\
\hline & Pembuatan KRS dan KTM & & & & & & 1 & 1 & 1 & & 2 & & & 2 & & 1 & & & & & & & & & \\
\hline & Pelaksanaan Perkuliahan & & & & & 2 & 1 & 1 & \begin{tabular}{|c|ccc}
1 & & $r$ \\
\end{tabular} & 1 & 2 & 1 & & 3 & & 1 & & & & 1 & & & & & \\
\hline & Evaluasi Akademik & & & & & & & & & & & & & & & & & & & & & & & & \\
\hline & Pelaksanaan Ujian & 1 & & & & & 1 & 1 & 1 & 1 & 1 & 1 & 1 & & 3 & & & & & & 2 & 3 & 1 & & \\
\hline & Pengolahan Nilai & & & & & & 1 & 1 & & 1 & 1 & & & & 1 & 3 & & & & & & & & & \\
\hline & Cuti Akademik & & & & & & 1 & 1 & & & & & & . & & & 3 & & & & & . & & & \\
\hline & $\begin{array}{l}\text { Pelaksanaan sidang / seminar } \\
\text { TA/Skripsi }\end{array}$ & & & & & & 1 & 1 & & 1 & & & 1 & 1 & & & & 3 & & & & 3 & & & \\
\hline & Pelaporan Akademik & & 1 & & 1 & & 1 & \begin{tabular}{|llll}
1 & & & \\
\end{tabular} & 1 & \begin{tabular}{|l|llll}
1 & & & & \\
\end{tabular} & 1 & & & 1 & $\begin{array}{llllll}1 & & r & r & \\
\end{array}$ & $1 \mid$ & 1 & 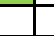 & 3 & 1 & & & 1 & 1 & 1 \\
\hline \multirow{4}{*}{ 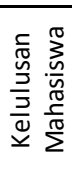 } & Penetapan Yudisium & & & & & & & & & & & & & & & & & & & & & & & & \\
\hline & $\begin{array}{l}\text { Pembuatan Ijazah dan Transkrip } \\
\text { Nilai }\end{array}$ & & & & & & 1 & 1 & 1 & & 1 & & & 1 & 1 & 2 & & & & 2 & & & & & \\
\hline & Pendaftaran wisuda & 1 & & & & & 1 & 1 & & & & & & & & 1 & & 1 & & 3 & & & & & \\
\hline & Pelaksanaan Wisuda & 1 & & & & & 1 & 1 & & & & & & & & & & & & 1 & & & & & \\
\hline \multirow{3}{*}{ 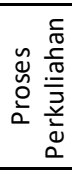 } & Monitoring Proses Perkuliahan & & & & & & & & & & & & & & & & & & & & & & & & \\
\hline & $\begin{array}{l}\text { Pemantauan Kehadiran Mhs per } \\
\text { tatap muka }\end{array}$ & & & & & & 1 & 1 & & 1 & 1 & 1 & 1 & 1 & & & & & & & 3 & & & & \\
\hline & $\begin{array}{l}\text { Pemantauan penyampaian materi } \\
\text { per tatap muka }\end{array}$ & & & & & & & & 1 & 1 & 1 & 1 & & & & & & & & & 1 & 3 & 1 & & \\
\hline \multirow{7}{*}{ 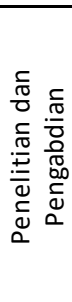 } & Penelitian & & & & & & & & & & & & & & & & & & & & & & & & \\
\hline & Perencanaan Kegiatan Penelitian & & & & & & 1 & \begin{tabular}{|c|lll}
1 \\
\end{tabular} & & 1 & & & & & & & & & & & & 3 & & 3 & \\
\hline & Pelaksanaan Kegiatan Penelitian & & & & & & 1 & & & 1 & & & & & & & & & & & & 2 & & 2 & \\
\hline & Pelaporan Hasil Penelitian & & & & & & & & & 1 & & & & & & & & & 3 & & & 2 & & 2 & \\
\hline & Pengabdian Masyarakat & & & & & & & & & & & & & & & & & & & & & & & & \\
\hline & $\begin{array}{l}\text { Perencanaan Kegiatan } \\
\text { Pengabdian Masy }\end{array}$ & & & & & & 1 & 1 & & 1 & & & & & & & & & & & & 3 & & & 3 \\
\hline & $\begin{array}{l}\text { Pelaporan Kegiatan Pengabdian } \\
\text { Masy }\end{array}$ & & & & & & & & & 1 & & & & & & & & & 3 & & & 2 & & & 2 \\
\hline \multirow{3}{*}{$\sum_{0}$} & Pengelolaan SDM & & & & & & & 1 & & 3 & & & & & & & & & & & 3 & & & & \\
\hline & Manajemen Tenaga Kependidikan & & & & & & & & & & & & & & & & 3 & & & & 3 & & & & \\
\hline & Manajemen Dosen & & & & & & & & & 2 & & & & & & & & & & & 1 & & & & \\
\hline \multirow{2}{*}{ 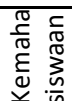 } & Pengelolaan Prestasi Mahasiswa & & & & & & 1 & 1 & & & & & & & & 1 & & & 3 & & & 3 & & & \\
\hline & Pengelolaan PKM & & & & & & 1 & 1 & & & & & & & & & & & 3 & & & 3 & & & \\
\hline
\end{tabular}

Keterangan: $1=\mathrm{R}:$ Read/Reference, $2=\mathrm{RU}:$ Read - Update, $3=\mathrm{CRU}:$ Create - Read - Update 
Mukhtar Hanafi, Ardhin Primadewi, Sunarni

Jurnal RESTI (Rekayasa Sistem dan Teknologi Informasi) Vol . 2 No. 1 (2018) 337 - 344

b) Pemetaan fungsi bisnis ke aplikasi (x,y)

Setiap aplikasi yang telah didefinisikan dihubungkan dengan area fungsi bisnis. Hubungan antara aplikasi dengan area fungsi bisnis adalah dalam hal pengolahan dan penggunaan aplikasi untuk keperluan pemenuhan tujuan fungsi bisnis. Lebih jelasnya dapat dilihat pada Tabel 2 .

Pada Tabel 2 baris yang berwarna kuning merupakan representasi klasifikasi pada fungsi bisnis. Dari fungsi bisnis yang ada maka akan dipetakan pada aplikasi yang diimplementasikan. Warna hijau pada aplikasi merupakan aplikasi yang belum terealisasi saat ini pada sistem di PDSI UMMagelang. Sedangkan warna hijau yang tersebar baik pada angka 1, 2 ataupun 3 menunjukkan bahwa aplikasi ini belum teraplikasikan pada sistem di PDSI UMMagelang. c) Pemetaan aplikasi ke entitas data $(y, z)$

Setiap entitas data yang telah didefinisikan dihubungkan dengan aplikasi. Hubungan antara entitas data dengan aplikasi adalah dalam hal data dapat dikolektif menggunakan aplikasi mana saja. Lebih jelasnya dapat dilihat pada Tabel 3.

Pada Tabel 3 aplikasi yang ada akan dipetakan pada entitas data yang dibutuhkan. Warna hijau pada entitas data merupakan entitas data yang belum terealisasi saat ini pada sistem di PDSI UMMagelang. Sedangkan warna hijau yang tersebar baik pada angka 1, 2 ataupun 3 menunjukkan bahwa data ini belum teraplikasikan pada sistem di PDSI UMMagelang.

Tabel 2 Aliran Data Matriks Relasi Aplikasi terhadap Fungsi Bisnis

\begin{tabular}{|c|c|c|c|c|c|c|c|c|c|c|c|c|c|c|c|c|c|c|c|}
\hline & Aplikasi & 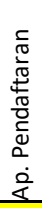 & 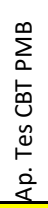 & 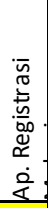 & 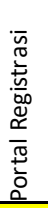 & 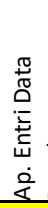 & 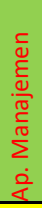 & 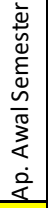 & 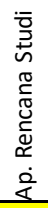 & $\begin{array}{l}\frac{5}{0} \\
\frac{\pi}{0} \\
\frac{0}{0} \\
0 \\
\frac{0}{0} \\
0 \\
\frac{0}{4} \\
\dot{0}\end{array}$ & 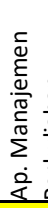 & 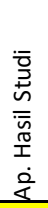 & 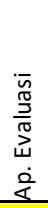 & $\begin{array}{l}\frac{1}{0} \\
\frac{0}{0} \\
\frac{0}{\pi} \\
\frac{0}{2} \\
\frac{0}{4}\end{array}$ & 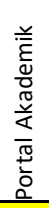 & $\begin{array}{l}\frac{5}{0} \\
\frac{0}{3} \\
\frac{3}{Q} \\
\frac{a}{u} \\
\frac{d}{4}\end{array}$ & $\begin{array}{l}\frac{\pi}{0} \\
\frac{0}{3} \\
\frac{0}{3} \\
\frac{\pi}{50} \\
\frac{0}{0} \\
2\end{array}$ & 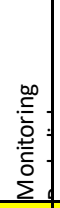 & 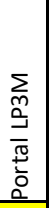 \\
\hline \multirow{9}{*}{$\sum_{a}^{\infty}$} & Perencanaan kegiatan PMB & & & & & & & & & & & & & & & & & & \\
\hline & $\begin{array}{l}\text { Penetapan Standarisasi dan } \\
\text { Kapasitas Mhs }\end{array}$ & 2 & 1 & 1 & 1 & 3 & & 1 & & & & & 1 & & & & & & \\
\hline & Pembuatan Jadwal PMB & 3 & 1 & 2 & 1 & & & 2 & & & & & & & & & & & \\
\hline & Proses PMB & & & & & & & & & & & & & & & & & & \\
\hline & Penyusunan Materi Ujian PMB & 1 & 3 & & & 3 & & & & & & & & & & & & & \\
\hline & $\begin{array}{l}\text { Penerimaan pendaftaran calom } \\
\text { MABA }\end{array}$ & 3 & 1 & & & & & & & & & & & & & & & & \\
\hline & Pelaksanaan Ujian Seleksi Masuk & 1 & 3 & & & 1 & & & & & & & & & & & & & \\
\hline & $\begin{array}{l}\text { Pemeriksaan Hasil UjianSeleksi } \\
\text { Masuk }\end{array}$ & 1 & 1 & & & & & & & & & & & & & & & & \\
\hline & Penetapan Kelulusan Calon MABA & 2 & 1 & 3 & 1 & 2 & & & & & & & & & & & & & \\
\hline \multirow{19}{*}{ 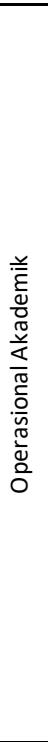 } & $\begin{array}{l}\text { Perencanaan Operasional } \\
\text { Akademik }\end{array}$ & & & & & & & & & & & & & & & & & & \\
\hline & Penetapan Kurikulum & & & 1 & 1 & & 3 & & & & & & & & 1 & & & & \\
\hline & Penetapan Kalender Akademik & & & 1 & 1 & & & 3 & & & & & & & 1 & & & & \\
\hline & Penetapan Dosen & & & & & & & 3 & & 2 & & & & & 1 & & & & \\
\hline & Penawaran Mata Kuliah & & & 1 & 1 & & & 3 & & & & & & & 1 & & & & \\
\hline & Penyusunan Jadwal Kuliah & & & 2 & 1 & & & 3 & 1 & 2 & & & & & 1 & & & & \\
\hline & Penetapan Ruang Kuliah & & & & & & & 3 & & 3 & & & & & 1 & & & & \\
\hline & Kebijakan Akademik & & & & & & & & & & & & & & & & & & \\
\hline & Registrasi Mahasiswa Lama & & & 3 & 1 & & & 1 & 3 & & & 1 & & & 1 & & & & \\
\hline & Bimbingan Akademik & & & 2 & 1 & 2 & & 1 & 2 & & & 1 & & & 1 & & & & \\
\hline & Pemrosesan Rencana Studi & & & 1 & 1 & & & 1 & 3 & 3 & & 1 & & & 1 & & & & \\
\hline & Pembuatan KRS dan KTM & & & 1 & 1 & 2 & & 1 & 1 & & & & & & 1 & & & & \\
\hline & Pelaksanaan Perkuliahan & & & 1 & 1 & & & 1 & 3 & 3 & & 1 & & & 1 & & & & \\
\hline & Evaluasi Akademik & & & & & & & & & & & & & & & & & & \\
\hline & Pelaksanaan Ujian & & & 1 & 1 & 1 & & & 1 & 1 & & & 3 & & 1 & & & 1 & \\
\hline & Pengolahan Nilai & & & 1 & & 2 & & & 1 & 1 & & 3 & & & & & & 1 & \\
\hline & Cuti Akademik & & & 3 & 1 & 2 & & & 1 & & & & & & 1 & & & & \\
\hline & $\begin{array}{l}\text { Pelaksanaan sidang / seminar } \\
\text { TA/Skripsi }\end{array}$ & & & 1 & 1 & 2 & & & 1 & & & & & & & & & & \\
\hline & Pelaporan Akademik & 1 & & 1 & 1 & 1 & 1 & 1 & 1 & 1 & & 1 & & & & 1 & 1 & 1 & \\
\hline \multirow{4}{*}{ 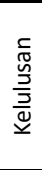 } & Penetapan Yudisium & & & & & & & & & & & & & & & & & & \\
\hline & $\begin{array}{l}\text { Pembuatan ljazah dan Transkrip } \\
\text { Nilai }\end{array}$ & & & 1 & & 2 & 1 & & 1 & & & 1 & & & & 1 & 1 & & \\
\hline & Pendaftaran wisuda & & & & & 3 & & & & & & 1 & & & 1 & 1 & 3 & & \\
\hline & Pelaksanaan Wisuda & & & & & 2 & & & & & & & & & & 1 & 1 & & \\
\hline
\end{tabular}

Jurnal RESTI (Rekayasa Sistem dan Teknologi Informasi) Vol . 2 No. 1 (2018) 337 - 344 
Mukhtar Hanafi, Ardhin Primadewi, Sunarni

Jurnal RESTI (Rekayasa Sistem dan Teknologi Informasi) Vol . 2 No. 1 (2018) 337 - 344

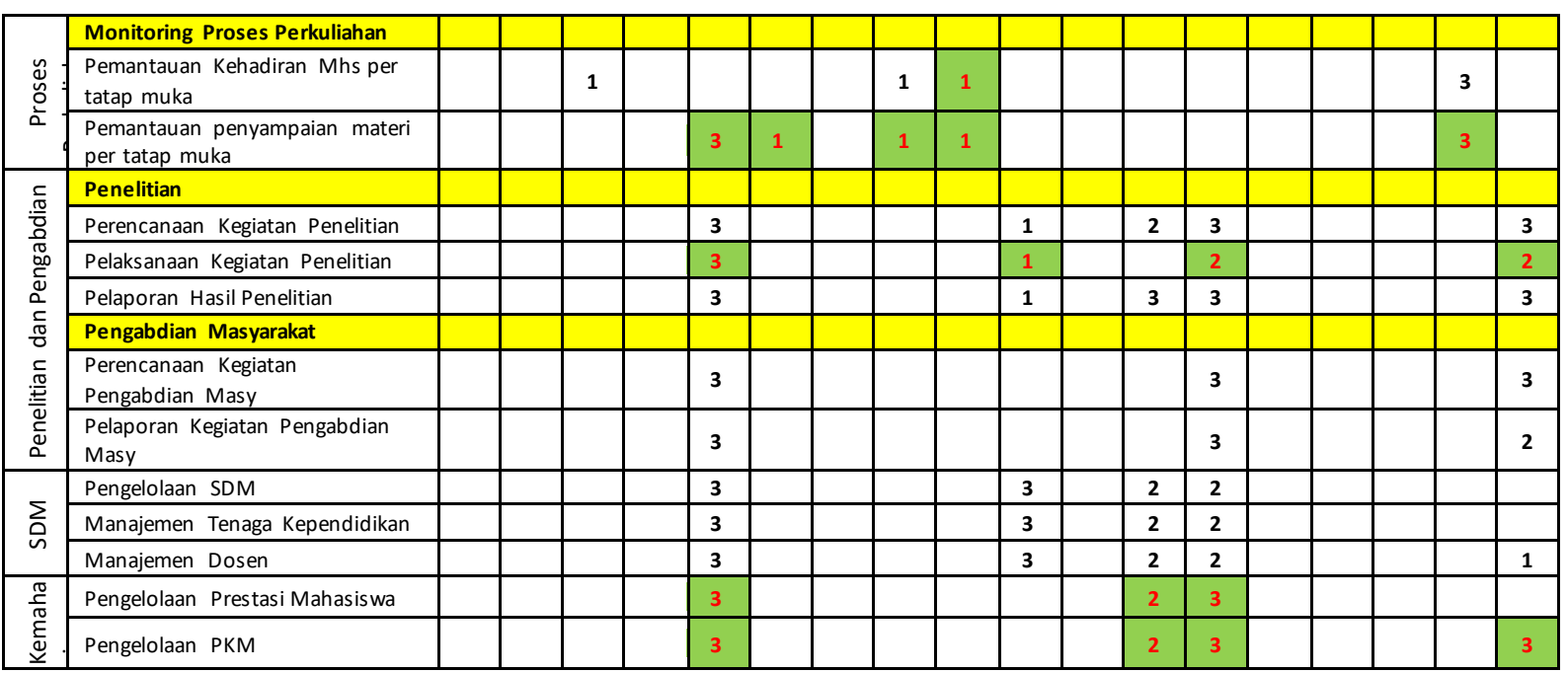

Keterangan: 1 = R : Read/Reference, 2 = RU: Read - Update, 3 = CRU $:$ Create - Read - Update

Tabel 3. Aliran Data Matriks Relasi Entitas Data terhadap Aplikasi

\begin{tabular}{|c|c|c|c|c|c|c|c|c|c|c|c|c|c|c|c|c|c|c|c|c|c|c|c|c|c|}
\hline Data & 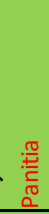 & 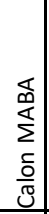 & 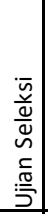 & 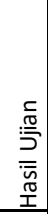 & 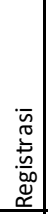 & 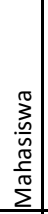 & 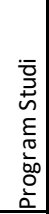 & 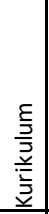 & 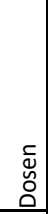 & 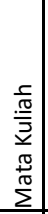 & 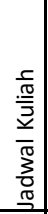 & 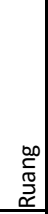 & 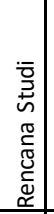 & 営 & $\frac{\bar{\pi}}{\bar{z}}$ & 恶 & 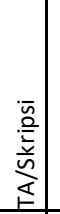 & $\begin{array}{l}\frac{c}{0} \\
\frac{\pi}{2} \\
\frac{0}{\Xi}\end{array}$ & $\begin{array}{l}\frac{\xi}{3} \\
: \frac{\bar{m}}{\overline{3}} \\
\bar{\nu}\end{array}$ & $\begin{array}{l}\frac{\pi}{3} \\
3 \\
3 \\
3\end{array}$ & 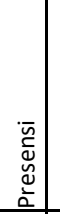 & 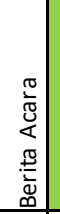 & 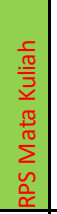 & 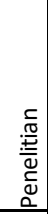 & 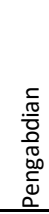 \\
\hline $\begin{array}{l}\text { Ap. Pendaftaran } \\
\text { Calon Mhs Baru }\end{array}$ & 1 & 3 & 2 & 1 & & & 1 & & & & & & & & & & & & & & & & & & \\
\hline $\begin{array}{l}\text { Ap. Tes CBT } \\
\text { PMB }\end{array}$ & 1 & 1 & 3 & 2 & & & 1 & & & & & & & & & & & & & & & & & & \\
\hline $\begin{array}{l}\text { Ap. Registrasi } \\
\text { Mhs }\end{array}$ & 1 & 1 & & 1 & 3 & 3 & 1 & 1 & & 1 & & & & & & & & & & & & & & & \\
\hline Po1tal Registrasi & & 1 & & 1 & 1 & 2 & 1 & 1 & 1 & 1 & & & 3 & & & & & & & & & & & & \\
\hline $\begin{array}{l}\text { Ap. Entri Data } \\
\text { Penukung }\end{array}$ & 1 & & 2 & & 2 & 2 & & 2 & & & & & & & & & 2 & 3 & & 3 & & 3 & 3 & 3 & 3 \\
\hline $\begin{array}{l}\text { Ap. Manajemen } \\
\text { Kurikulum }\end{array}$ & 1 & & & & & & 1 & 3 & & 3 & & & & & & & & & & & & & & & \\
\hline $\begin{array}{l}\text { Ap. Awal } \\
\text { Semester }\end{array}$ & & & 2 & & 3 & & 1 & 3 & & 3 & 3 & 3 & & & & & & & & & & & & & \\
\hline $\begin{array}{l}\text { Ap. Rencana } \\
\text { Studi }\end{array}$ & & & & & 3 & 2 & 1 & 1 & & 1 & 1 & 1 & 3 & & & 1 & & & & & & & & & \\
\hline $\begin{array}{l}\text { Ap. Pengelolaan } \\
\text { Peserta Kelas }\end{array}$ & & & & & 1 & 1 & 1 & & 2 & 1 & 2 & 1 & 1 & & & & & & & & 3 & & & & \\
\hline $\begin{array}{l}\text { Ap. Manajemen } \\
\text { Perkuliahan }\end{array}$ & & & & & & 1 & 1 & 1 & 1 & 1 & 1 & 1 & 1 & & & & & 2 & 2 & & 3 & 3 & 3 & & \\
\hline Ap. Hasil Studi & & & & & & 1 & 1 & & 1 & 1 & & & 1 & 1 & 3 & & & & 2 & & & & & & \\
\hline Ap. Evaluasi & 1 & 1 & 1 & 1 & 1 & 1 & 1 & 1 & 1 & 1 & 1 & & & & & & 1 & 1 & & 1 & 1 & & 1 & 1 & 1 \\
\hline Ap. Laporan & & 1 & & 1 & & 1 & 1 & 1 & 1 & 1 & & & 1 & 1 & 1 & 1 & 1 & 3 & 1 & 1 & 1 & & & 1 & 1 \\
\hline Portal Akademik & & & & & & 1 & 1 & 1 & 1 & 1 & 1 & 1 & 1 & 1 & 1 & 1 & 1 & & 1 & 1 & 1 & & & & \\
\hline Ap. Kelulusan & & & & & & 1 & 1 & 1 & & 1 & & & 1 & & 1 & & 1 & & 3 & 1 & & & & & \\
\hline Portal Wisuda & & & & & & 1 & 1 & & & & & & & & 1 & & 1 & & 1 & 3 & & & & & \\
\hline $\begin{array}{l}\text { Monitoring } \\
\text { Perkuliahan }\end{array}$ & & & & & & 1 & 1 & & 1 & 1 & 1 & 1 & 1 & & & & & & & & 3 & 3 & 1 & & \\
\hline Portal LP3M & & & & & & & & & 1 & & & & & & & & & 3 & & & & 3 & & 3 & 3 \\
\hline
\end{tabular}

Keterangan: $1=\mathrm{R}:$ Read/Reference, $2=\mathrm{RU}:$ Read - Update, $3=\mathrm{CRU}:$ Create - Read - Update

\section{Kesimpulan}

5.1 Simpulan
UMMagelang, sebagai Biro pengembang sistem informasi tataran institusi. Pada awal penelitian, ditemukan bahwa sistem informasi yang dikembangkan

Pengembangan pelayanan pada civitas akademika pada oleh PDSI belum dikembangkan secara terarah. Hal ini UMMagelang sangat tergantung pada PDSI 
ditunjukkan dengan masih adanya entitas data utama yang belum diimplementasikan.

Berdasarkan pada Gambar 4 "Value chain analysis fungsi bisnis UMMagelang", dapat diketahui bahwa proses penerimaan mahasiswa baru dan proses akademik merupakan aktivitas utama. Namun demikian dalam pelaksanaannya, distribusi entitas data yang dibutuhkan belum sepenuhnya terakomodir pada fungsi bisnis yang ada pada institusi.

Entitas data yang belum diimplementasikan dapat dilihat pada tabel 1 dan 3 pada kolom yang berwarna hijau. Hal ini berdampak pada kurangnya pengembangan aplikasi yang dapat mengakomodir data tersebut (terlihat pada tabel 2). Pada tabel 1 dapat dilihat bahwa data kepanitiaan PMB belum tersimpan sehingga belum dapat mendukung fungsi bisnis perencanaan kegiatan PMB. Pada tabel 1 juga dapat dilihat bahwa RPS Mata Kuliah pada entitas data belum ada. Sehingga fungsi bisnis yang merujuk pada proses perkuliahan masih belum sempurna dikarenakan masih belum adanya data terkait RPS Mata Kuliah. Pada tabel 2 dapat dilihat bahwa aplikasi yang belum ada untuk menunjang fungsi bisnis yang ada yaitu aplikasi manajemen kurikulum dan manajemen perkuliahan. Dari keseluruhan proses yang dilalui, dapat dilihat bahwa pemodelan data dengan merelasikan 3 variabel yaitu fungsi bisnis, entitas data dan aplikasi akan memudahkan dalam mengetahui posisi-posisi mana yang perlu segera dibenahi.

\subsection{Saran}

Saran yang dapat diberikan sebagai tindak lanjut dari hasil penelitian ini adalah adanya kelanjutan pemodelan sistem informasi dan pemodelan teknologi informasi yang akan menjadi model utuh dalam pemodelan perguruan tinggi berdasarkan pada pemodelan arsitektur data yang telah dikembangkan pada penelitian ini.

\section{Daftar Rujukan}

[1] D. Nurnaningsih, "Enterprise Architecture Planning Untuk
Pengembangan Sistem Informasi Akademik Menggunakan Zachman Framework," J. Tek., vol. 6, no. 2, pp. 72-82, 2017. [2] N. Hilda, "Strategi Inovasi Layanan dalam Meningkatkan Kualitas Pelayanan di Kantor Pertanahan Kota Surabaya II," in Kebijakan dan Manajemen Publik, 2014, vol.2, no. 1, pp. 1-10.

[3] D. M. Khairina, Mustafid, and B. Noranita, "Enterprise Architecture Planning Untuk Pengembangan Sistem Informasi Perguruan T inggi," J. Sist. Inf. Bisnis, vol. 3, pp. 117-123, 2012.

[4] A. Setiawan, "Evaluasi penerapan teknologi informasi di perguruan tinggi swasta Yogy akarta dengan menggunakanmodel Cobit framework," in Seminar Nasional Aplikasi Teknologi Informasi (SNATI), 2009, p. A-15.

5] I. Silanegara, B. T ama, and D. Nurhidayat, "Perencanaan Strategis Teknologi Informasi (Studi Kasus: Politeknik Negeri Jakarta)," J. Generic, vol. 6, no. 1, pp. 13-18, 2013.

[6] S. Warnars, "Rancangan Infrastruktur E- Bisnis Business Intelligence pada Perguruan T inggi," Telkomnika, vol.6,p.6930, 2008.

[7] A. Primadewi, U. Yudatama, and S. Nugroho, "Pengukuran Tingkat Kematangan Pengembangan Business Teknologi Informasi dan Komunikasi (TIK) Perguruan Tinggi,"J.Rekayasa Sist. dan Teknol. Inf., vol. 1, no. 1, pp. 34-42, 2017.

8] M.-H. Chuah and K.-L. Wong, "A review of business intelligence and its maturity models," African J. Bus. Manag., vol.5,no.9,pp. 3424-3428, 2011.

[9] S. Romayah, A. Suroso, and A. Ramadhan, "Evaluasi Implementasi E-government di Instansi XYZ," J. Apl. Manaj., vol. 12 , no. 4, pp. $612-620,2014$

[10]A. Kurniawan, Y. N. Kunang, and S. D. P. Sari, "Penerapan Dashboard Business Intelligence Pada Penelitian , Pelayanan / Pengabdian Kepada Masyarakat Dan Kerjasama," Palembang, 2016.

[11]T. Suryana, "Perancangan Arsitektur Teknologinformasidengan Pendekatan Enterprise Architecture Planning," Universitas Komputer Indonesia. Bandung, pp. 223-236, 2012.

[12]R. Yunis and K. Surendro, "Implementasi EnterpriseArchitecture Perguruan Tinggi," in Seminar Nasional Aplikasi Teknologi Informasi, 2010 , p. A-51.

[13]D. Khairina, M. Mustafid, and B. Noranita, "Enterprise Architecture Planning untuk Pengembangan Sistem Informasi Perguruan Tinggi," Universitas Diponegoro, 2012.

[14]J. M. Nogueira, D. Romero, J. Espadas, and A. Molina, "Leveraging the Zachman framework implementation using action - research methodology - a case study: aligning the enterprise architecture and the business goals," J. Enterp. Inf. Syst., vol. 7, no. 1, pp. 100-132, 2013. 